\title{
ANALISIS PENGARUH RASIO KEUANGAN TERHADAP PERUBAHAN LABA PADA PT. ULTRA JAYA MILK INDUSTRI DAN TRADING COMPANY TBK
}

\author{
Pertiwi Puspa Wardani', Muhammad Abdi Akbar Idris ${ }^{2}$, Herman Sjahruddin ${ }^{3}$ \\ 1,2,3) Sekolah Tinggi Ilmu Ekonomi Makassar Bongaya, Sulawesi Selatan \\ Penulis Korespondensi : Pertiwipuspa3@gmail.com ${ }^{1),} \underline{\text { abdiakbar@msn.com }}^{2)}$ herman.sjahruddin@ @mail.com ${ }^{3)}$
}

\begin{abstract}
Abstrak
Penelitian ini bertujuan untuk menguji pengaruh rasio keuangan yang ditunjukkan melalui debt to asset ratio, total assets turn over ratio, dan net profit margin terhadap perubahan laba pada PT. Ultra Jaya Milk Industri \& Trading Company Tbk. Populasi dalam penelitian ini yaitu seluruh laporan keuangan PT. Ultra Jaya Milk Industry dan Trading Company, Tbk periode 2010-2018. Sampel penelitian menggunakan 9 tahun pengamatan, sehingga jumlah data yang digunakan adalah 9 Tahun $x$ 4 triwulan $=36$ sampel pengamatan. Alat analisis yang digunakan adalah software SPSS v.22. Hasil penelitian menunjukkan bukti bahwa debt to asset ratio dan net profit margin tidak berpengaruh terhadap perubahan laba, sedangkan total assets turn over ratio berpengaruh positif dan signifikan terhadap perubahan laba.
\end{abstract}

Keywords: Debt to asset ratio, total assets turn over ratio, net profit margin, perubahan laba. 


\section{PENDAHULUAN}

PT. Ultrajaya Milk Industry \& Trading Company Tbk (ULTJ) merupakan salah satu perusahaan yang terdaftar di Bursa Efek Indonesia yang bergerak dalam bidang industri makanan dan minuman, dan bidang perdagangan. Di bidang minuman Ultrajaya memproduksi rupa-rupa jenis minuman seperti susu cair, sari buah, teh, minuman tradisional dan minuman kesehatan, yang diolah dengan teknologi UHT (Ultra High Temperature) dan dikemas dalam kemasan karton aseptik. Di bidang makanan Ultrajaya memproduksi susu kental manis, susu bubuk, dan konsentrat buahbuahan tropis (www.ultrajaya.co.id, diakses 20 Februari 2020).

Tingginya persaingan usaha pada sub sektor makanan dan minuman berdampak pada perolehan laba perusahaan, laba atau keuntungan merupakan salah satu tujuan utama perusahaan dalam menjalankan aktivitasnya Pihak manajemen selalu merencanakan besar perolehan laba setiap periode. Laba yang diperoleh perusahaan akan digunakan untuk berbagai kepentingan oleh pemilik dan manajemen. Laba akan digunakan untuk meningkatkan kesejahteraan pemilik dan karyawan atas jasa yang diperolehnya. Laba juga digunakan sebagai penambahan modal dalam rangka meningkatkan kapasitas produksi atau untuk melakukan perluasan pemasaran (Surwarni, 2015).

Fluktuasi laba disebut juga dengan pertumbuhan atau perubahan laba. Pihak manajemen senantiasa menginginkan perolehan laba yang tinggi pada setiap periode pelaporan keuangan perusahaan. Laba yang diperoleh perusahaan akan digunakan untuk berbagai kepentingan pemilik dan pihak manajemen. Laba perusahaan akan digunakan untuk meningkatkan kesejahteraan pemilik dan karyawan atas jasa yang diperolehnya. Laba juga digunakan sebagai penambahan modal dalam rangka meningkatkan kapasitas produksi atau untuk melakukan perluasan pemasaran (Winarni, 2015).

Perubahan laba yang tinggi diakibatkan karena perusahaan mampu melakukan perencanaan laba yang baik. Perencanaan laba merupakan perencanaan yang dilakukan oleh perusahaan agar dapat mencapai tujuan dari perusahaan yaitu memperoleh laba. Perencanaan laba berisikan langkah-langkah yang akan ditempuh oleh perusahaan untuk mencapai besarnya target laba yang diinginkan. Laba merupakan tujuan utama dari perusahaan karena laba memiliki selisih antara pendapatan yang diterima (dari hasil penjualan) dengan biaya yang dikeluarkan, maka perencanaan laba dipengaruhi oleh perencanaan penjualan. Perencanaan laba memiliki hubungan antara biaya, volume dan harga jual. Biaya menentukan harga jual untuk mencapai tingkat laba yang dikehendaki, harga jual mempengaruhi volume penjualan, sedangkan volume penjualan mempengaruhi volume produksi (Munawir, 2007:184).

Perolehan Laba perusahaan sangat bergantung pada penjualan yang dilakukan perusahaan, jika penjualan perusahaan tinggi dan biaya operasional dapat ditekan seminimal mungkin, maka laba perusahaan semakin tinggi, sebaliknya jika tidak. Pernyataan tersebut menujukkan bahwa laba tidak bersifat tetap, pada beberapa satuan ukuran waktu pelaporan keuangan di temukan adanya perubahan laba. Perubahaan laba merupakan naik atau turunnya laba perusahaan yang akan mempengaruhi keputusan investasi para investor maupun calon investor yang akan menanamkan modalnya ke perusahaan (Pramono, 2015),

Terjadinya perubahan laba disebabkan oleh aktivitas keuangan perusahan (Kasmir, 2014: 53). Aktivitas keuangan di ukur dengan rasio keuangan, yang merupakan perbandingan angka-angka yang diperoleh dari data laporan keuangan, sehingga dapat di jelaskan bahwa keterkaitan antara rasio keuangan dan laba, jika rasio keuangan perusahaan berada pada tingkat yang tinggi maka laba perusahaan (kecuali kewajiban atau utang perusahaan) maka laba perusa-haan dapat di tingkatkan (Kasmir, 2014: 53). Berdasarkan pada laporan keu-angan perusahaan, maka perubahan laba dapat ditunjukkan pada Tabel berikut:

\section{Tabel 1.}

Perubahan Laba PT. Ultra Jaya Milk Industri \& Trading Company Tbk Tahun 2017 - 2018 (dalam Rupiah)

\begin{tabular}{|c|c|c|c|}
\hline \multirow{2}{*}{ Triwula- } & \multicolumn{2}{|c|}{ Perubahan Laba } & \multirow{2}{*}{ Perubahan } \\
\hline & 2017 & 2018 & \\
\hline
\end{tabular}

TR-1 240.993.425.168 $171.893 .000 .000 \quad-69.100 .425 .168$

TR-2 $386.461 .674 .675 \quad 365.518 .000 .000 \quad-20.943 .674 .675$

TR-3 $552.646 .816 .454 \quad 621.886 .000 .000 \quad-30.760 .816 .454$

TR-4 711.681.000.000 701.607.000.000 -10.074 .000 .000$

Mean 497.945.729.074 465.226.000.000 -3 2.719.729.074 
Sumber: www.ultrajaya.co.id (data diolah 2020).

Tabel 1. menjelaskan bahwa jika dibandingkan perolehan laba perusahaan dari tahun 2017 dengan 2018, secara rata-rata ditemukan adanya penurunan laba perusahaan sebesar -32.719.729.074. Penurunan tersebut disebabkan karena beban penjualan tercacat meningkat dari 1,45 Milyar Rupiah ditahun 2017 naik menjadi 1,67 Milyar Rupiah (www.cnbcindonesia.com/market, diunduh 20 Februari 2020).

Penilaian tingkat keuntungan investasi oleh investor didasarkan oleh kinerja keuangan perusahaan, dapat dilihat dari tingkat perubahan laba dari tahun ke tahun (Oktanto, D., dan Amin, M. N., 2014). Para investor dalam menilai perusahaan tidak hanya melihat laba dalam satu periode melainkan terus memantau perubahan laba dari tahun ke tahun, prediksi laba dan atau kinerja laba dapat dilakukan melalui rasio keuangan yang pada dasarnya tidak hanya berguna bagi kepentingan intern perusahaan, melainkan juga bagi pihak eksternal. Selain itu, rasio keuangan dapat dipakai sebagai sistem peringatan awal (early warning system) terhadap kemunduran kondisi keuangan dari suatu perusahaan (Oktanto, D., dan Amin, M. N., 2014).

Melalui rasio keuangan, investor dapat dibimbing untuk membuat keputusan atau perimbangan tentang apa yang akan dicapai oleh perusahaan dan bagaimana prospek yang akan dihadapi di masa yang akan datang. Rasio keuangan meliputi (1) rasio likuiditas; (2) rasio solvabilitas; (3) rasio aktivitas; dan (4) rasio profitabilitas (Ifada, L. M., dan Puspitasari, T., 2016).

Temuan peneliti terdahulu membuktikan bahwa Debt to asset ratio (DAR) mempunyai pengaruh signifikan dengan arah negatif pada perubahan laba (Oktanto dan Muhammad Nuryatno, 2014). Namun, hasil berbeda ditunjukkan pada studi yang dilakukan Agustina dan Silvia, (2012), bahwa DAR berpengaruh signifikan dengan arah positif terhadap perubahan laba.

Determinan yang mempengaruhi perubahan laba berdasarkan temuan peneliti terdahulu adalah total asset turn over (TATO), bahwa TATO berpengaruh positif dan signifikan terhadap pertumbuhan laba (Nindhika, dkk., 2014). Namun, hasil berbeda ditunjukkan penelitian lainnya, bahwa TATO berpengaruh negatif dan signifikan terhadap perubahan laba. (Sitanggang dan Yacob, 2015).

Kausalitas lainnya yang mempengaruhi perubahan laba ditunjukkan melalui net profit margin (NPM), bahwa NPM mempunyai pengaruh positif dan signifikan terhadap perubahan laba perusahaan (Lestari, 2014). Namun, hasil berbeda ditunjukkan penelitian lainnya bahwa NPM justru berpengaruh negatif dan signifikan terhadap perubahan laba. (Syarifah, 2014).

Tinggi ataupun rendahnya laba perusahaan dipengaruhi banyak faktor, berdasarkan pandangan teori sinyal yang menjelaskan bahwa segala bentuk informasi keuangan yang di berikan kepada investor merupakan pembentuk terciptanya kepercayaan inverstor terhadap perusahaan. Kepercayaan investor akan semakin tinggi apabila perusahaan mampu menyajikan informasi laba perusahaan secara periodik yang bersumber dari laporan keuangan perusahaan (Ifada, L. M., dan Puspitasari, T., 2016; Lorenza, dkk., 2020; Harris dkk.,2020).

Pengumuman laba merupakan salah satu bentuk penyampaian informasi keuangan. Pengumuman laba memuat informasi yang dipakai para investor untuk membuat keputusan pada kegiatan investasi serta memproyeksikan atau memperkirakan prospek/harapan perusahaan di masa yang akan datang. Apabila pihak manajemen perusahaan mengumumkan laba yang naik, investor akan menerima informasi bahwa kondisi keuangan perusahaan relatif baik di masa yang akan datang. Tetapi apabila manajemen mengumumkan laba yang turun/rendah, investor akan menerima informasi bahwa kondisi keuangan perusahaan relatif tidak baik di masa yang akan datang (Ifada, L. M., dan Puspitasari, T., 2016).

Pertumbuhan atau perubahan laba mempunyai hubungan erat dengan kinerja keuangan perusahaan. Laba yaitu suatu parameter/indikator untuk melihat apakah kinerja keuangan suatu perusahaan mengalami peningkatan atau penurunan. Perubahan peningkatan atau penurunan tersebut akan memberikan dampak pada keputusan mengenai kebijakan keuangan perusahaan. Analisis rasio keuangan merupakan suatu alat untuk mengetahui kinerja keuangan perusahaan.

Berdasarkan teori dan temuan peneliti terdahulu maka penelitian ini bertujuan untuk menguji pengaruh debt to asset ratio, total 
assets turn over ratio dan net profit margin terhadap perubahan laba.

\section{TINJAUAN PUSTAKA Solvabilitas}

Rasio solvabilitas merupakan rasio yang digunakan untuk mengukur seberapa besar perusahan dibiyai dengan utang. apabila perusahan memiliki rasio leverage yang tinggi (memiliki utang yang besar), hal ini akan berdampak timbulnya risiko keuangan yang besar tetapi perusahaan memiliki peluang yang besar pula untuk memperoleh laba yang tinggi, sebaliknya apabila perusahaan memiliki risiko keuangan yang kecil tetapi memiliki peluang kecil pula untuk memperoleh laba yang tinggi. (Hery, 2015).

\begin{abstract}
Aktivitas
Rasio aktivitas merupakan rasio yang digunakan untuk mengukur tingkat efisiensi atas pemanfaatan sumber daya yang dimiliki perusahaan, atau untuk menilai kemampuan perusahaan dalam menjalankan aktivitasnya sehari-hari (hery, 2017).
\end{abstract}

\section{Profitabilitas}

Rasio profitabiltas merupakan rasio untuk menilai kemampuan perusahaan dalam mencari keuntungan. Rasio ini juga memberikan ukuran tingkat efektifitas manajemen suatu perusahan. (Kasmir, 2014;196).

\section{METODE PENELITIAN}

Penelitian ini menggunakan pendekatan kuantitatif yaitu menggunakan cara berpikir deduktif. Sedangkan berdasarkan tingkat eksplanasinya, penelitian ini tergolong penelitian asosiatif. Penelitian asosiatif adalah penelitian yang bertujuan untuk mengetahui pengaruh atau hubungan sebab akibat, yaitu variabel bebas atau independen (X) terhadap variabel terikat atau dependen (Y) (Prawiroharjo Thauwrisan, L., 2016).

Populasi dalam penelitian ini yaitu seluruh laporan keuangan PT. Ultra Jaya Milk Industry dan Trading Company, Tbk periode 2010-2018 dilihat dari laporan per triwulan, sehingga jumlah observasi adalah 9 tahun $\mathrm{x} 4$ triwulan $=36$ pengamatan. Sampel penelitian adalah bagian dari jumlah dan karakteristik yang dimiliki oleh populasi. Jenis sampel yang digunakan adalah sampel jenuh. Karena sampel dalam penelitian ini hanya PT. Ultra Jaya Milk
Industry dan Trading Company dengan periode laporan keuangan 2010-2018 dilihat laporan per triwulan, sehingga jumlah tahun pengamatan dalam penelitian ini dilakukan selama 9 tahun pengamatan, sehingga jumlah observasi adalah 9 tahun $x 4$ triwulan $=36$ sampel pengamatan.

Penelitian menggunakan bentuk pengumpulan data atau desain cross-sectional, yang merupakan suatu jenis penelitian yang dilakukan dengan cara mengumpulkan data pada satu waktu yang sama selama satu periode hari, minggu atau bulan maupun tahun (Susanto, 2013:67). Dengan jenis data yang digunakan adalah jenis data kuantitatif. Data yang dimaksud dalam penelitian ini adalah edebt to asset ratio, total assets turn over ratio, net profit margin, dan perubahan laba.

Sumber data dalam penelitian ini adalah data sekunder yang diperoleh dari lembaga atau instansi yang berhubungan dengan objek penelitian dan didapatkan melalui dokumendokumen, yaitu data dari Laporan Keuangan Publikasi pada periode tahun 2010-2018 yang diterbitkan oleh PT. Ultra Jaya Milk Industri \& Trading Company Tbk. Teknik pengumpulan data yang digunakan adalah teknik dokumentasi, yaitu teknik yang dilakukan dengan cara mengumpulkan, mencatat, dan mengkaji data sekunder yang berupa data laporan keuangan.

\section{HASIL DAN PEMBAHASAN}

Uji Normalitas digunakan untuk untuk menguji apakah dalam model regresi variabel independen dan variabel dependen memiliki distribusi data normal atau tidak (Ghozali, 2016:154). Model regresi yang baik adalah memiliki distribusi normal atau mendekati normal. Uji normalitas data dapat dilakukan dengan menggunakan One Sample Kolmogorov-Smirnov yaitu dengan ketentuan apabila nilai signifikan diatas 0,05 , maka data terdistribusi normal. Sedangkan, jika hasil One Sample Kolmogorov-Smirnov menunjukkan nilai signifikan dibawah 0,05 , maka data tidak terdistribusi normal.

Tabel 2. Hasil Uji Normalitas

\begin{tabular}{|c|c|}
\hline Konstruk & $\begin{array}{c}\text { Unstandardized } \\
\text { Residual }\end{array}$ \\
\hline $\mathrm{N}$ & 36 \\
\hline Test Statistic & 20.91483 \\
\hline $\begin{array}{l}\text { Asymp. Sig. (2- } \\
\text { tailed) }\end{array}$ & .612 \\
\hline
\end{tabular}


Berdasarkan data output SPSS diatas, dapat diketahui bahwa nilai test statistic sebesar $20.91483>0.05$ dan nilai KolmogorovSmirnov (KS) sebesar $0.612>0.05$, maka dapat dinyatakan bahwa data yang diuji berdistribusi normal.

Uji Autokorelasi bertujuan menguji apakah dalam model regresi linear ada korelasi antara kesalahan pengganggu pada periode $t$ dengan kesalahan pengganggu pada periode $\mathrm{t}-1$ (sebelumnya) (Ghozali, $2016: 155$ ).

Hasil uji autokorelasi pada model summary menunjukkan bahwa nilai Durbin-Watson sebesar 1.812, pembanding menggunakan nilai signifikan 5\% (0.05). Jumlah sampel sebanyak 36 (n) dan jumlah variabel independen $3(\mathrm{k}=3)$, maka pada tabel Durbin-Watson akan diperoleh nilai dL sebesar 1.2953, nilai dU sebesar 1.6539. Karena nilai Durbin-Watson 1.812 berada diluar daerah antara nilai dL dan nilai $\mathrm{dU}$ atau $\mathrm{dL}<\mathrm{d}<\mathrm{dU}$, maka tidak terdapat autokorelasi.

Uji Multikolonieritas Model regresi yang baik seharusnya tidak terjadi korelasi di antara variabel independen (Ghozali, 2016:103). Untuk mendeteksi ada atau tidaknya multikolonieritas di dalam model regresi dapat dilihat dengan nilai Tolerance (TOL) dan Variance Inflation Factor (VIF).

Tabel 3. Hasil Uji Multikolonieritas

\begin{tabular}{ccc}
\hline Independen & \multicolumn{2}{c}{ Collinearity Statistics } \\
\cline { 2 - 3 } variabel & Tol. & VIF \\
\hline DAR & .313 & 3.198 \\
TATO & .894 & 1.119 \\
NPM & .316 & 3.166 \\
\hline
\end{tabular}

Berdasarkan data output SPSS diatas, dapat diketahui bahwa: hasil pengujian nilai Tolerance dari variabel independen DAR sebesar $0.313>0.10$ dan nilai VIF sebesar $3.198<10.00$, sehingga dengan demikian dapat dinyatakan bahwa data hasil pengujian tidak terjadi multikolonieritas. Hasil pengujian nilai Tolerance dari variabel independen TATO sebesar $0.894>0.10$ dan nilai VIF sebesar $1.119<10.00$, sehingga dengan demikian dapat dinyatakan bahwa data hasil pengujian tidak terjadi multikolonieritas. Hasil pengujian nilai Tolerance dari variabel independen NPM sebesar $0.316>0.10$ dan nilai VIF sebesar $3.166<10.00$, sehingga dengan demikian dapat dinyatakan bahwa data hasil pengujian tidak terjadi multikolonieritas.

Uji Heterokedastisitas bertujuan menguji apakah dalam model regresi terjadi ketidaksamaan varian dari residual satu pengamatan ke pengamatan lain. Jika varian dari residual dari satu pengamatan ke pengamatan yang lain tetap, maka disebut Homokedastisitas. Dan jika varian berbeda disebut Heterokedastisitas. Model regresi yang baik adalah tidak terjadi heteroskedastisitas (Ghozali, 2016:134).

Tabel 4. Hasil Uji Heterokedastisitas

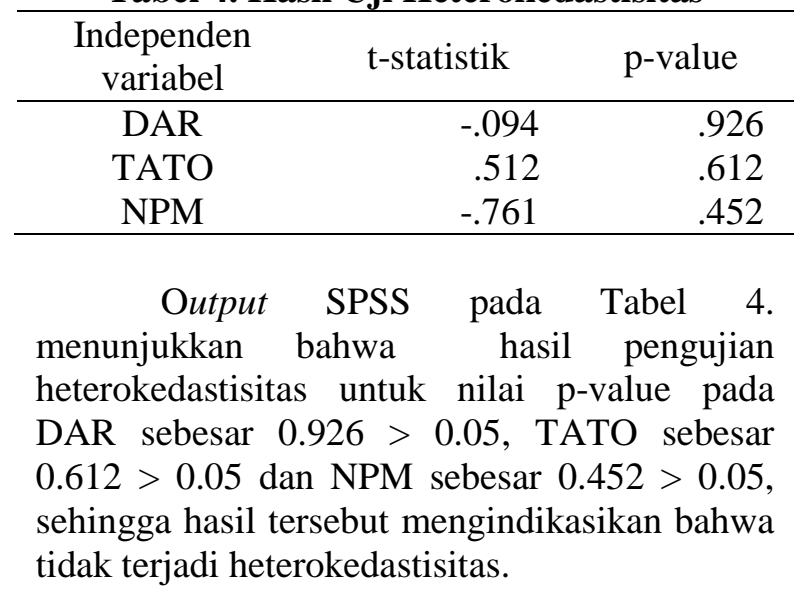

Uji Linearitas digunakan untuk mengetahui apakah dua variabel mempunyai hubungan yang linear atau tidak secara signifikan (Ghozali, 2016:105). Kriteria dalam uji linearitas adalah dua variabel dikatakan mempunyai hubungan yang linear apabila nilai deviation from linearity (Signifikant) > 0,05.

Tabel 5. Hasil Uji Linearitas

\begin{tabular}{lcrr}
\hline Dependen & Independen & $\begin{array}{c}\mathrm{t}- \\
\text { statistik }\end{array}$ & $\begin{array}{c}\mathrm{p}- \\
\text { value }\end{array}$ \\
\hline \multirow{3}{*}{ Per.Laba } & DAR & .978 & .335 \\
& TATO & 2.440 & .193 \\
& NPM & .140 & .712 \\
\hline
\end{tabular}

Berdasarkan hasil perhitungan tersebut, menunjukkan bahwa: (1) Adanya hubungan linear antara debt to asset (DAR) terhadap perubahan laba dengan deviation from linearity p-value $=0.335>0,05$. (2) Adanya hubungan linear antara total assets turn over (TATO) terhadap Perubahan Laba dengan deviation from linearity $\mathrm{p}$-value $=0.193>0,05$. (3) 
Adanya hubungan linear antara net profit margin (NPM) terhadap Perubahan Laba dengan deviation from linearity $\mathrm{p}$-value $=0.712$ $>0,05$.

\section{Analisis Statistik Deskriptif}

Analisis statistik deskriptif adalah statistik yang memberikan gambaran atau mendeskripsikan data menjadi sebuah informasi yang lebih jelas dan mudah dipahami (Ghozali, 2016:19).

Tabel 6. Statistik Deskriptif

\begin{tabular}{crrr}
\hline Variabel & Mean & $\begin{array}{c}\text { Std. } \\
\text { Deviation }\end{array}$ & N \\
\hline P_Laba & 112.1111 & 491.62697 & 36 \\
DAR & 25.1944 & 7.47498 & 36 \\
TATO & 68.3611 & 32.27839 & 36 \\
NPM & 11.1944 & 3.88270 & 36 \\
\hline
\end{tabular}

Berdasarkan hasil statistic deskriptif, dapat dilihat bahwa dalam penelitian ini sampel (N) yang digunakan sebanyak 36 data, pada perincian data analisis statistik deskriptif masing-masing variabel independen dan variabel dependen, nilai rata-rata (mean) dan standar deviasi.

Pada variabel perubahan laba nilai ratarata (mean) sebesar 112.1111, dengan nilai standar deviasi sebesar 491.62697. Nilai ratarata (mean) yang lebih kecil ini menunjukkan bahwa hasil deskriptif variabel yang digunakan adalah kurang baik.

Nilai rata-rata (mean) variabel DAR sebesar 25.1944, dengan nilai standar deviasi sebesar 7.47498. Maka nilai rata-rata (mean) yang lebih besar ini dapat dinyatakan bahwa terjadi peningkatan nilai, sehingga hasil deskriptif variabel yang digunakan adalah baik.

Nilai rata-rata (mean) variabel TATO sebesar 68.3611, dengan nilai standar deviasi sebesar 32.27839. Hal ini dapat dinyatakan bahwa terjadi peningkatan fluktuasi nilai yang disebabkan besarnya nilai rata-rata dibandingkan nilai standar deviasinya.

Nilai rata-rata (mean) variabel NPM sebesar 11.1944, dengan nilai standar deviasi sebesar 3.88270. Maka nilai rata-rata (mean) yang lebih besar ini dapat dinyatakan bahwa terjadi peningkatan nilai, sehingga hasil deskriptif variabel yang digunakan adalah baik.

\section{Uji Regresi Linear Berganda}

Penentuan terdapat ataupun tidaknya pengaruh yang positif signifikan ataupun sebaliknya, dapat dilihat pada nilai t-hitung dan p-value, untuk itu hasilnya dapat ditunjukkan sebaagai berikut:

Tabel 7. Hasil Uji Regresi Linear Berganda

\begin{tabular}{crrr}
\hline Independen & Beta & $\begin{array}{c}\text { Std. } \\
\text { Error }\end{array}$ & $\begin{array}{c}\mathrm{t}- \\
\text { statistik }\end{array}$ \\
\hline DAR & - & 18.308 & -.491 \\
& 8.987 & & \\
TATO & 6.669 & 2.508 & 2.659 \\
NPM & -.625 & 35.067 & -.018 \\
\hline
\end{tabular}

Berikut hasil dari pengujian yang telah dilakukan:

$\mathrm{Y}_{\left(\mathrm{P} \_L a b a\right)}=-110.348_{\text {(Kons. })}-8.987_{(\mathrm{DAR})}+$ $6.669_{\text {(TATO) }}-0.625_{(\mathrm{NPM})}+889.980_{(\mathrm{e})}$

Dari persamaan regresi tersebut, dapat dijelaskan sebagai berikut :

1) Angka konstanta sebesar -110.348 menyatakan jika debt to asset $\left(\mathrm{X}_{1}\right)$, total assets turn over $\left(\mathrm{X}_{2}\right)$ dan net profit margin $\left(\mathrm{X}_{3}\right)$ nilainya 0 , maka perubahan laba $(\mathrm{Y})$ nilainya sebesar -110.348 .

2) Koefisien DAR sebesar -8.987 menyatakan bahwa setiap penambahan $1 \%$ DAR, maka akan menurunkan perubahan laba sebesar 8.987 pada saat variabel lainnya tidak berubah (konstan).

3) Koefisien TATO sebesar 6.669 menyatakan bahwa setiap penambahan $1 \%$ TATO, maka akan meningkatkan perubahan laba sebesar 6.669 pada saat variabel lainnya tidak berubah (konstan).

4) Koefisien NPM sebesar -.625 menyatakan bahwa setiap penambahan $1 \%$ NPM, maka akan menurunkan perubahan laba sebesar .625 pada saat variabel lainnya tidak berubah (konstan).

\section{Uji Kelayakan Model Uji Fisher Test}

Tabel 8. Hasil Uji Fisher Test

\begin{tabular}{ccc}
\hline Model & F & p-value \\
\hline Regression & 3.091 & $.041^{\mathrm{b}}$
\end{tabular}

Nilai F-tabel berpedoman pada nilai df1 dan df2 sehingga berdasarkan pada tabel diatas, maka nilai df 1 dan df 2 yaitu 3 dan 32. Penentuan nilai F-tabel dilakukan dengan menggunakan bantuan MS-Excel melalui penggunaan 
formulasi $\quad \mathrm{FINV}=(0.05,3,32), \quad$ sehingga diperoleh nilai F-tabel dalam penelitian ini yaitu 2.90. Maka berdasarkan hasil hitung menggunakan formulasi FINV, dapat disimpulkan bahwa nilai F-hitung lebih besar daripada F-tabel $(3.091>2.90)$ dan nilai signifikansinya lebih kecil dari 0.05 (0.041 < 0.05), maka model yang disusun memenuhi kriteria kelayakan model.

\section{Uji Student test}

Tabel 9. Hasil Uji Student test

\begin{tabular}{ccc}
\hline Independen & t-statistik & p-value \\
\hline DAR & -.491 & .627 \\
TATO & 2.659 & .012 \\
NPM & -.018 & .986 \\
\hline
\end{tabular}

Nilai t-tabel berpedoman pada nilai $\mathrm{df}=(\mathrm{n}-\mathrm{k}-1)$ sehingga diperoleh nilai df sebesar $32=(36-3-1)$. Penghitungan nilai t-tabel dilakukan dengan menggunakan MS-Excel melalui penggunaan formulasi $\quad \mathrm{TINV}=(0.05,32), \quad$ sehingga memperoleh nilai t-tabel sebesar 2.037. Berdasarkan hasil SPSS, dapat disimpulkan bahwa hanya TATO yang berpengaruh positif dan signifikan terhadap perubahan laba.

\section{Uji Koefisien Determinasi $\left(\mathbf{R}^{2}\right)$}

\section{Tabel 10. Hasil Uji Koefisien Determinasi}

\begin{tabular}{ccc}
\multicolumn{3}{c}{$\left(\mathbf{R}^{2}\right)$} \\
\hline $\mathrm{R}$ & \multicolumn{2}{c}{ R Square } \\
\hline & \multicolumn{4}{c}{.225} \\
\hline
\end{tabular}

Hasil output SPSS pada tabel 10., menunjukkan bahwa nilai uji koefisien determinasi $\left(\mathrm{R}^{2}\right)$ sebesar 0.225 yang berarti menunjukkan pengaruh antar variabel independen yaitu DAR, TATO, dan NPM terhadap variabel dependen yaitu perubahan laba sebesar $22.5 \%$. Hal ini mengartikan bahwa perubahan laba (Y) dapat dipengaruhi oleh DAR $\left(\mathrm{X}_{1}\right)$, TATO $\left(\mathrm{X}_{2}\right)$ dan NPM $\quad\left(X_{3}\right)$, sedangkan sisanya $77.55 \%$ dipengaruhi oleh faktor-faktor lain yang tidak dijelaskan dalam penelitian ini.

\section{1) Debt to Asset Ratio (DAR) Terhadap Perubahan Laba}

Hasil uji $t$ variabel DAR terhadap perubahan laba diperoleh nilai t-hitung $=-0.491$ dengan $p$-value $0.627>$ p-value, sehingga hasil ini memberikan bukti bahwa $\mathrm{H}_{1}$ ditolak dan $\mathrm{H}_{0}$ diterima. Variabel DAR mempunyai t-hitung yaitu -0.491 dengan t-tabel 2.037, sehingga nilai t-hitung < t-tabel $(-0.491<2.037)$ sehingga hasil tersebut menunjukkan bahwa DAR tidak memberikan kontribusi terhadap perubahan laba. Jadi dapat disimpulkan bahwa DAR tidak berpengaruh terhadap perubahan laba.

Hasil penelitian ini berbeda dengan penelitian yang dilakukan Luluk Muhimatul Ifada dan Tiara Puspitasari (2016) menemukan bahwa debt to asset ratio mempunyai pengaruh negatif dan signifikan pada perubahan laba pada perusahaan manufaktur yang terdaftar di Bursa Efek Indonesia (BEI) tahun 2011-2013. Penolakan temuan juga ditunjukkan pada studi yang dilakukan Oktanto dan Muhammad Nuryatno, (2014), bahwa Debt to asset ratio (DAR) mempunyai pengaruh signifikan dengan arah negatif pada perubahan laba. Agustina dan Silvia, (2012) bahwa DAR berpengaruh signifikan dengan arah positif terhadap perubahan laba.

\section{2) Total Assets Turn Over (TATO) Terhadap Perubahan Laba}

Nilai TATO terhadap terhadap perubahan laba berdasarkan hasil uji t-statistik diperoleh nilai t-hitung $=2.659$ dengan $\mathrm{p}$-value $=0.012$, dengan $p$-value $=0.010<0.05$, sehingga dari hasil tersebut dapat dikemukakan bahwa $\mathrm{H}_{1}$ diterima dan $\mathrm{H}_{0}$ ditolak. Variabel TATO mempunyai t-hitung yaitu 2.659 dengan t-tabel 2.037, sehingga nilai t-hitung > t-tabel (2.659> 2.037) dan menyatakan bahwa TATO memiliki kontribusi terhadap perubahan Laba. Jadi dapat disimpulkan bahwa TATO memiliki pengaruh positif dan signifikan terhadap perubahan laba.

Hasil penelitian ini sesuai dengan penelitian yang dilakukan Luluk Muhimatul Ifada dan Tiara Puspitasari (2016); Nindhika, dkk., (2014) bahwa total assets turnover mempunyai pengaruh positif dan signifikan terhadap perubahan laba. Namun, hasil berbeda ditunjukkan penelitian lainnya, bahwa TATO berpengaruh negatif dan signifikan terhadap perubahan laba. (Sitanggang dan Yacob, 2015).

\section{3) Net Profit Margin (NPM) Terhadap Perubahan Laba}

Hasil pengujian NPM terhadap perubahan laba diperoleh nilai t-hitung - 0.018 dengan nilai signifikan 0.986. Nilai signifikansi yang lebih besar dari p-value 0.05 atau $0.986>0.05$, menjadi dasar pengambilan keputusan, bahwa $\mathrm{H}_{1}$ ditolak dan $\mathrm{H}_{0}$ diterima. Variabel NPM 
mempunyai t-hitung yaitu -0.018 dengan t-tabel 2.037, sehingga nilai t-hitung $<\mathrm{t}$-tabel $(-0.018$ $<$ 2.037) dengan demikian dapat dinyatakan bahwa NPM tidak memiliki kontribusi terhadap perubahan laba. Sehingga dapat disimpulkan bahwa NPM tidak berpengaruh terhadap perubahan laba.

Hasil penelitian ini tidak sesuai dengan penelitian yang dilakukan Yaya Sonjaya (2012); Lestari, (2014), bahwa net profit margin secara parsial berpengaruh positif secara signifikan terhadap perubahan laba. NPM berpengaruh negatif dan signifikan terhadap perubahan laba. (Syarifah, 2014).

\section{KESIMPULAN}

Rendahnya debt to asset ratio dan net profit margin yang dimiliki perusahaan tidak dapat berkontribusi dalam meningkatkan perubahan laba. Namun perubahan laba dapat meningkat dengan total assets turn over yang dimiliki perusahaan. Perubahan laba merupakan informasi penting bagi investor untuk membuat keputusan investasi, yang terlebih dahulu menuntut investor untuk memperkirakan prospek perusahaan di masa yang akan datang. Jika laba mengalami kenaikan maka minat investor akan semakin tinggi demikian juga sebaliknya. Kondisi yang dialami perusahaan menegaskan bahwa salah satu alasan investor untuk berinvestasi diakibatkan karena total assets turn over perusahaan yang mengalami kenaikan selama periode pengamatan sehingga perubahan laba mengalami kenaikan.

Penelitian ini memberikan rekomendasi kepada investor tentang pentingnya nilai total assets turn over sebagai pertimbangan pengambilan keputusan keuangan dalam melakukan investasi. Kepada peneliti lanjutan disarankan untuk menambah area pengamatan sehingga dengan luasnya pengamatan akan diperoleh determinan penentu perubahan laba.

\section{DAFTAR PUSTAKA}

Agustina dan Silvia. (2012). Pengaruh Rasio Keuangan terhadap Perubahan Laba pada Perusahaan Manufaktur yang Terdaftar di BEI. Jurnal Wira Ekonomi Mikroskil. Vol. 2, Nomor 2, Oktober 2012.

Ang, Robert. (1997). Buku Pintar Pasar Modal Indonesia. Jakarta: Mediasoft Indonesia.
Bambang Hermanto, Sri Rahayu, dan Yudi. (2018). Pengaruh Rasio Keuangan Terhadap Perubahan Laba (Studi Empiris Pada Bank Pembangunan Daerah Se-Sumatera) Tahun 20112017. Jurnal Ilmu Akuntansi Pascasarjana Universitas Jambi.

Darsono dan Ashari.(2005). Pedoman Praktis Memahami Laporan Keuangan. Andi. Yogyakarta.

Engelwati Gani dan Almitra Indira. (2011). Analisa Rasio Keuangan Untuk Memprediksi Perubahan Laba Pada Perusahaan Telekomunikasi Indonesia. Binus Business Review Vol. 2 No. 2 November 2011: 883-898

Fahmi, Irham. (2012). Analisis Laporan Keuangan. Bandung: Alfabeta

Ghozali, Imam. (2016). Aplikasi Analisis Multivariate dengan Program IBM SPSS Semarang: Universitas Diponegoro.

Hanafi, Mamduh dan Abdul Halim. (2012). Analisis Laporan Keuangan. Edisi empat, UPP STIM YKPN, Yogyakarta

Harahap, Sofyan Syafri. (2016). Analisis Kritis atas Laporan Keuangan. Penerbit PT. Raja Grafindo Persada, Jakarta.

Harris, M. I., Sjahruddin, H., \& Themba, O. S. (2020). Kontribusi Rasio Aktivitas dan Ukuran Perusahaan pada Rentabilitas PT. Telekomunikasi Indonesia (Persero), Tbk. Jurnal SEKURITAS (Saham, Ekonomi, Keuangan dan Investasi), 3(3), 219-229.

Hasnawati, S. (2005). Implikasi Keputusan Investasi, Pendanaan, dan Dividen Terhadap Nilai Perusahaan Publik di Bursa Efek Jakarta. Jurnal Usahawan XXXIX (9): 33-41.

Jumingan. (2011). Analisis Laporan Keuangan. Jakarta: PT Bumi Aksara.

Kasmir. (2014). Analisis Laporan Keuangan. Jakarta: Raja Grafindo Persada.

Lestari, Sri. (2014). Analisis Pengaruh Rasio Keuangan dalam Memprediksi Perubahan Laba pada Perusahaan BUMN yang Terdaftar di BEI Periode 2007-2011. Karya Ilmiah. Surakarta.

Lorenza, D., Kadir, M. A., \& Sjahruddin, H. (2020). Pengaruh Struktur Modal Dan Ukuran Perusahaan Terhadap Profitabilitas Pada Perusahaan 
Otomotif Yang Terdaftar Di BEI. Jurnal Ekonomi Manajemen, 6(1), 13-20.

Luluk Muhimatul Ifada dan Tiara Puspitasari. (2016). Analisis Pengaruh Rasio Keuangan Terhadap Perubahan Laba. Jurnal Akuntansi dan Auditing Volume 13/No. 1 Tahun 2016: 97-108.

Martono, dan Harjito D. (2010). Manajemen Keuangan. Yogyakarta: Ekonisia.

Munawir, S. (2007). Analisa Laporan Keuangan. Edisi Keempat, Penerbit Liberty, Yogyakarta.

Nindhika Paramawardhani, Tatang Ary Gumanti, dan Novi Puspitasari. (2014). Rasio Keuangan Dan Perubahan Laba Perusahaan Agroindustri Di Bursa Efek Indonesia. Jurnal Pasca Sarjana Universitas Jember.

Oktanto, Danny dan Muhammad Nuryanto. (2014). Pengaruh Rasio Keuangan Terhadap Perubahan Laba Pada Perusahaan Manufaktur Yang Terdaftar Di Bursa Efek Indonesia (BEI) Tahun 2008-2011. Vol.1, No.1.

Sitanggang,Rohana dan Yacob Vivandi. (2015).Rasio Keuangan terhadap Laba pada Perusahaan. Jurnal Manajemen Bisnis Transportasi dan Logistik.Vol.1, Nomor 2, Januari2015.

Syarifah, Siti. (2014). Pengaruh Rasio Leverage dan Profitabilitas terhadap Perubahan Laba pada Perusahaan Sektor Aneka Industri yang Terdaftar di Bursa Efek Indonesia. Jurnal Universitas Maritim Raja Ali Haji JurusanAkuntansi.

Subramanyam dan Wild. (2013). Analisis Laporan Keuangan. Jakarta: Salemba Empat

Sugiyono. (2017). Statistik Untuk Penelitian. Cetakan Kedua Puluh Tujuh, Penerbit: Alfabeta, Bandung.

Suroto. (2015). Pengaruh Keputusan Investasi, Keputusan Pendanaan dan Kebijakan Deviden Terhadap Nilai Perusahaan. (Studi Empiris Pada Perusahaan LQ45 Yang Terdaftar Di Bursa Efek Indonesia Periode Februari 2010Januari 2015). Jurnal Ilmiah UNTAG. Vol. 4, No. 3, 2015.

Suwardjono. (2014). Teori Akuntansi Perekayasaan Pelaporan Keuangan. Yogyakarta: BPFE. Universitas Gajah Mada.
Van Horne, James C. dan Wachowicz Jr, John M. (2005). Prinsip-Prinsip Manajemen Keuangan. Buku Satu. Edisi Kedua Belas. Alih Bahasa oleh Dewi Fitriasari dan Deny Arnos Kwary. Salemba Empat. Jakarta.

Winarni. (2015). Pengaruh Rasio Likuiditas, Rasio Solvabilitas, Rasio Aktivitas Terhadap Perubahan Laba (Studi pada Perusahaan Manufaktur yang Tercatat di Bursa Efek Indonesia Pada Tahun 2011-2013). Jurnal Ekonomi dan Bisnis Universitas Dian Nuswantoro Semarang.

Yaya Sonjaya. (2012). Pengaruh Rasio Keuangan Terhadap Perubahan Laba pada Perusahaan Otomotif Yang Terdaftar di Bursa Efek Indonesia. Jurnal Future. 